\title{
Present Status of Groundwater in India
}

\author{
Sudhir K. Parmar \\ (Assistant Professor, Civil Engineering Department, Galgotia College of Engineering \& Technology, Greater \\ Noida., India).
}

\begin{abstract}
The present status of groundwater in many States of India has reached to a level of crisis. The solutions of this problem are demanding an urgent attention at many fronts. The distribution of replenishable ground water by river basins is quite skewed and thus national average level of ground water development as $58 \%$ of the available potential in the aggregate is misleading. The available data is analysed to define a critical factor as level of groundwater development (in percent) per unit percentage of villages having tubewell irrigation that can be incorporated for available ground water resources for irrigation (in MCM/year). This critical factor for most of the States is quite in agreement with the percentages of the overexploited/critical blocks of the concerned State, except Maharashtra.
\end{abstract}

Keywords: Critical factor, Integrated Water Development Schemes, Overexploited and critical blocks, Skewed distribution of replenishable ground water resources, Unplanned groundwater extraction

\section{Introduction}

The development of ground water irrigation in India has a pivotal effect to contribute more than $70 \%$ of food production. The pace of its development was so high that present percentage of irrigated land by ground water is more than 60 .The challenges that ground water irrigation is facing today are of the status of a crisis. The solutions of this problem are demanding an urgent attention at many fronts. India has to manage its ground water resources in a way that growth and development of it in the future may not involve any risk of being in a state of serious implications. The present paper defines a term, critical ratio, which reflects the degree of severe consequences in a particular State. The paper analyses the available data to identify the critical States and suggest remedial measures.

\section{Skewed Distribution}

Central Ground Water Board has worked out national average level of ground water development as $58 \%$ of the available potential in the aggregate. It does not appear alarming but geographical distribution of replenishable ground water resources by river basins is quite skewed. The total replenishable ground water resources (BCM) for Ganga Basin is 39.6 percent of total replenishable ground water resources of $431.42 \mathrm{BCM}$ (Ministry of Water Resources,2007). Godavari (9.42 percent), Brahmputra (6.15 percent), Indus (6.14 percent), and Krishna (6.12 percent) are the other four river basins which are above 5 percent of total replenishable ground water resources in the country.

It reflects highly skewed distribution of replenishable ground water resources in India. The proportion of ground water in the total irrigation potential varies from state to state, ranging over 50 percent in Uttar Pradesh (55.1\%), Madhya Pradesh (54.3\%), Manipur (61.1\%), Tamil Nadu (51.2\%) and Jammu and Kashmir (52.1\%). This proportion is about 33 percent for Rajasthan, Kerala, Haryana and Assam. Punjab (48.9\%), West Bengal (48\%), Orissa(47.7\%), Gujarat (45.2\%), Karnataka (43.1\%), Maharashtra (40.8\%), Meghalaya (37.5\%), Bihar (37.1\%) and Andhra Pradesh (35.2\%) are in the range of 33 to 50 percent.

2.1 Level Of Ground Water Development: The level of ground water development is very high in Punjab (141\%), Rajasthan (111\%) and Haryana (105\%).The level of $180 \%$ of ground water development in Punjab means that net draft is $80 \%$ higher than the available ground water resources for irrigation. This is the state of serious concern. This data is adopted from various tables of Ministry of Water Resources \& Central Ground Water Board (CGWB) and compiled as shown in Table-1.The level of ground water development may not give a real picture, as we will find that the level of ground water development in Uttar Pradesh is 64.63\% only while many districts have reached the level of highly water stressed districts. Punjab has $141 \%$ of ground water development while $92.2 \%$ of its villages have tube well irrigation. On the other hand, Gujarat has $69.84 \%$ of ground water development, while only $50.6 \%$ of its villages have tube well irrigation .Thus in actual, Gujarat is a rather more water stressed state than Punjab, as proportionally the ground water development in Gujarat will be no less than $127 \%$ with comparatively lesser number of tube wells per village.

2.2 Statistics Of Other Data: The canal irrigation reduced from $39.78 \%$ in $1950-51$ to $26.26 \%$ in $2008-09$ while tube well irrigation rose from zero percent in $1950-51$ to $41.1 \%$ in 2008-09. Canal water irrigation was erratic and may not be available at the time of need. Ground water irrigation was available in time and was 
beneficial in overcoming the problem of water logging due to canal water irrigation. The factors responsible for ground water revolution were new modular well and pumping technology, cheap and un-metered electricity, credit availability and poor management of canal system. As of now, the present net area irrigated by private wells is about double the area irrigated by canals. The very speedy expansion of ground water irrigation resulted in fast decline of ground water table in the country.Table-2 shows categorization of blocks /talukas/watersheds as overexploited and dark and critical. Punjab, Uttar Pradesh, Haryana and Bihar are the States that have the proportion of villages having tube well irrigation above the national average $(63.1 \%)$. The with drawl rate is twice the recharge rate in India. And, this with drawl rate is something that is very alarming. The Rabi season takes a major share of ground water $(50 \%)$, while in Kharif season about $38 \%$ area is irrigated with ground water.

$68 \%$ of shallow tube wells are owned by small and marginal farmers having holdings below 2 hectares. Medium farmers owned $27.6 \%$ shallow tube wells. $70 \%$ of deep tube wells are owned by medium and large farmers. The distribution of deep tube wells is not equitable but distribution of shallow tube wells is reasonably equitable as two-thirds of them are owned by marginal and small farmers. Farmers having their own tube wells achieve the highest yield with next as those farmers purchasing water from well owners. The farmers dependent on canal irrigation alone are at the bottom. The farmers using water from public tube wells have yields higher than the farmers using canal water irrigation but less than those using water from their own tube wells or purchasing from private tube wells. The reason is obviously the availability of water at the time of need of the crop.

\section{The Critical Factor}

The data adopted from various tables of Ministry of Water Resources, 2007 and complied in Table-1 gives a alarming picture in terms of a critical factor, which is defined as level of ground water development (in percent) per unit percentage of villages having tube well irrigation that can be incorporated for available ground water resources for irrigation (in MCM/year).The higher this factor, more critical may be a State. But this critical factor does not reflect the actual picture of the crisis. It is an indicative factor and does not reflect a relative weightage. The actual percentages of villages in a state having tube well irrigation are different, but

Table 1 : Calculation of Critical Factor

\begin{tabular}{|c|c|c|c|c|c|c|c|}
\hline States & $\begin{array}{l}\text { Total replenishable } \\
\text { ground water } \\
\text { resources } \\
\text { (BCM/year) } \\
\text { (A) }\end{array}$ & $\begin{array}{l}\text { Availabl-e } \\
\text { ground water } \\
\text { resources for } \\
\text { irigation } \\
\text { (BCM/ye-ar) } \\
\text { (B) }\end{array}$ & $\begin{array}{l}\text { Net Draft } \\
(\mathrm{BCM} / \text { ye-ar) } \\
(\mathrm{C})\end{array}$ & $\begin{array}{l}\text { Level of ground } \\
\text { water } \\
\text { development(D } \\
=\text { C } / B)\end{array}$ & $\begin{array}{l}\text { Percenta-ge of } \\
\text { villages having } \\
\text { tube well } \\
\text { irigation(E) }\end{array}$ & $\begin{array}{l}\text { Percenta-ge of } \\
\text { villages that can } \\
\text { be incorpora-ted } \\
\text { for available } \\
\mathrm{GW} \text { resources } \\
(\mathrm{F}=\mathrm{EB} / \mathrm{C})\end{array}$ & $\begin{array}{l}\text { Criti- cal } \\
\text { Fact- or } \\
(\mathrm{G}=\mathrm{D} / \mathrm{F})\end{array}$ \\
\hline Punjab & 23.78 & 21.44 & 30.34 & 141.51 & 92.2 & & 1.53 \\
\hline Rajasthan & 11.56 & 10.38 & 11.60 & 111.75 & 54.3 & & 2.05 \\
\hline Haryana & 9.31 & 8.63 & 9.10 & 105.45 & 81.4 & 17.20 & 1.29 \\
\hline Tamil Nadu & 23.07 & 20.76 & 16.77 & 80.79 & 13.9 & 72.45 & 4.69 \\
\hline Gujarat & 15.81 & 15.02 & 10.49 & 69.84 & 50.6 & 100 & 0.96 \\
\hline Uttar Pradesh & 76.35 & 70.18 & 45.36 & 64.63 & 82.1 & 57.67 & 0.79 \\
\hline Uttrakhand & 2.27 & 2.10 & 1.34 & 63.80 & 36.8 & & 1.10 \\
\hline Kamataka & 15.93 & 15.3 & 9.75 & 63.72 & 59.3 & 20.82 & 1.07 \\
\hline Maharashtra & 32.96 & 31.21 & 14.24 & 45.62 & 9.5 & & 2.19 \\
\hline Madhya Pradesh & 37.19 & 35.33 & 16.08 & 45.51 & 40.6 & & 1.12 \\
\hline Andhra Pradesh & 36.50 & 32.95 & 13.88 & 42.12 & 43.80 & & 0.96 \\
\hline West Bengal & 30.36 & 27.46 & 10.84 & 39.47 & 43.90 & & 0.90 \\
\hline Bihar & 29.19 & 27.42 & 9.39 & 34.25 & 68.6 & & 0.50 \\
\hline Kerala & 6.84 & 6.23 & 1.82 & 29.21 & 7.0 & 23.96 & 1.21 \\
\hline Himachal Pradesh & 0.43 & 0.39 & 0.09 & 23.08 & 83.50 & & 0.27 \\
\hline Chhattisgarh & 14.93 & 13.68 & 2.31 & 16.89 & 44.60 & & 0.38 \\
\hline Orissa & 23.09 & 21.01 & 3.01 & 14.33 & 31.30 & & 0.46 \\
\hline Tripura & 2.19 & 1.97 & 0.08 & 4.06 & 38.50 & & 0.10 \\
\hline
\end{tabular}

Possible percentages of villages that can have tube well irrigation are calculated for available ground water resources for irrigation. However the assumption that tube well irrigation will develop for available ground water resources may not be feasible, as ground water may not be available or development may not be pursued due to different constraints. The other reasons may also be very significant. As shown in Table 2, the critical factors for most of the States are quite in agreement with the percentages of the overexploited/critical Blocks of the concerned State, except Maharashtra. The data of overexploited/critical Blocks so collected may not be the true representative of the entire State. Many times, the official figures of overexploited and critical Blocks are underestimated figures. The situation may be reaching alarming proportions in many regions of the country and we may still be un-warned. 
Table 2 : Comparison of Critical Factor with percentage of overexploited/ critical Blocks

\begin{tabular}{|l|l|l|l|}
\hline States & Critical Factor & $\begin{array}{l}\text { Percentage of overexploited } \\
\text { Blocks/Talukas/Watersheds }\end{array}$ & $\begin{array}{l}\text { Percentage of Dark/Critical } \\
\text { Blocks/Talukas/Watershed }\end{array}$ \\
\hline Punjab & 1.53 & 75.18 & 3.65 \\
\hline Rajasthan & 2.05 & 59.1 & 21.10 \\
\hline Haryana & 1.29 & 48.67 & 9.73 \\
\hline Tamil Nadu & 4.69 & 36.88 & 23.07 \\
\hline Gujarat & 0.96 & 13.90 & 5.19 \\
\hline Uttar Pradesh & 0.79 & 4.76 & 1.59 \\
\hline Uttarakhand & 1.1 & N.A & N.A \\
\hline Karnataka & 1.07 & 37.14 & 1.71 \\
\hline Maharashtra & 2.19 & 2.20 & 0.31 \\
\hline Madhya Pradesh & 1.12 & 7.69 & 1.60 \\
\hline Andhra Pradesh & 0.96 & 17.79 & 6.25 \\
\hline West Bengal & 0.90 & 0.0 & 0.37 \\
\hline Bihar & 0.50 & 0.0 & 0.0 \\
\hline Kerala & 1.21 & 3.31 & 9.93 \\
\hline Himachal Pradesh & 0.27 & 0.0 & 0.0 \\
\hline Chhattisgarh & 0.38 & 0.0 & 0.0 \\
\hline Orissa & 0.46 & 0.0 & 0.0 \\
\hline Tripura & 0.10 & & 0.0 \\
\hline
\end{tabular}

\section{Conclusion}

Though it is our failure not to have recorded the story of growth and development of groundwater irrigation in India, but we must not fail in recognizing the need of switching the alarm bells for unplanned ground water extraction any further. It is needed to identify the critical States and even the over exploited critical Blocks in non-critical States. The legislation must be in place to improve the status of the overexploited critical Blocks by (i) restricting unplanned and un-sanctioned extraction of ground water resources in overexploited and critical Blocks and imposing the policy of licensing for further digging of tube wells,(ii) making mandatory for the public the adoption of technology of recharging the ground water strata,(iii)ensuring the start of Integrated Water Development Scheme for at least 2-3 areas in a State every year on co-operative basis with effective peoples participation,(iv)separating the right to ground water from right to land, and (v)enforcing the proper price of water as expensive water will be used efficiently by the farmers. The use of drip or sprinkler irrigation and good land leveling can definitely reduce the irrigation water in the farms. Punjab has put the restrictions on the dates of planting of rice in the months of May and June to reduce water needs without any significant reduction in the yield. The development of the drought resistant varieties will ensure a better use efficiency.The institutional arrangement including Centre and state governments and local and water users institutions have failed to demonstrate the successful stories, except a few. The planning and management to save overexploitation of groundwater will need a major institutional reform of appropriate legal approach and policy of strict enforcement. In many parts of Gujarat, it has been successfully done. But, in India, even political pressures are active at local levels so that particular area may not be declared overexploited and thus affecting the statistics of the status of the groundwater. An effective awareness program about consequences of overexploitation of water may help. A government agency must be entrusted to record the status of groundwater of every block in every six months and dissemination of this information to the public through Water Users Associations (WUAs) to inform in clear words how fast a particular block is approaching to be critical. In North Gujarat, tube well depths have crossed 1000 feet, but the policies and much needed institutional changes are still awaited. The poor water quality problems are emerging even in the Krishna Delta, which is water rich delta in Andhra Pradesh. Groundwater salinity problem is also due to heavy groundwater extraction as because of it, intrusion of saline water from existing saline zones into fresh water takes place.

However, the critical factor is not in agreement with overexploited and critical blocks of Maharashtra, but the factor may be indicative of the alarming situation in the near future. A comparison of depth of water level during pre-monsoon 2013 with August 2013 reveals that in general, there is rise in water level except in Delhi, Punjab, Haryana, Rajasthan, Gujarat, Karnataka and Tamil Nadu. Also, a comparison of depth of water level of January 2014 with decadal mean of years 2004 to 2013 indicates a decline in the water level of more than $4 \mathrm{~m}$ in the states of Delhi, Gujarat, Haryana, Karnataka, Punjab, Rajasthan and Tamil Nadu.

\section{References}

[1]. Central Ground Water Board, Dynamic Ground Water Resources of India, Ministry of Water Resources, Government of India,Faridaba, 2006-07,2013-14.

[2]. Ministry of Water Resources, Third Census of Minor Irrigation schemes, Government of India, New Delhi, 2000-01.

[3]. Kanchan Chopra, C.H. Hanumantha Rao, Ramprasad Sengupta, Water resources and sustainable livelihoods \& eco-systems services (Concept Publishing Company, New Delhi,2003)

[4]. Kamta Prasad, Water resources and sustainable development: challenges of $21^{\text {st }}$ century (Shipra Publications,2003)

[5]. Bhatia, Bela, Lush Fields and Perched Throats: Political Economy of Groundwater in Gujarat, Economic \& Political weekly, vol 27,No 51-52,1992,142-170 